\title{
ОСОБЛИВОСТІ ЗМІН ЦИТОКІНОВОГО ПРОФІЛЮ КРОВІ ПРИ ЗАСТОСУВАННІ ТРИМЕТАЗИДИНУ ДЛЯ КОРЕКЦІ ЕКСПЕРИМЕНТАЛЬНОГО ДИФУЗНОГО ІШЕМІЧНО-НЕКРОТИЧНОГО КАРДІОСКЛЕРОЗУ У ЩУРІВ З РІЗНОЮ СТІЙКІСТЮ ДО ГІПОКСІ
}

\author{
(CГ. С. Сатурська \\ ДВНЗ «Тернопільський державний медичний університет імені І. Я. Горбачевського МОЗ України» \\ РЕЗЮМЕ. Використовуючи ендогенну метаболічну терапію для корекці дифузного ішемічно-некротичного \\ кардіосклерозу ми дослідили особливості цитокінового профілю в різні терміни спостереження у тварин із різною \\ резистентністю до гіпоксі . В експерименті підтверджено ефективність раннього застосування триметазидину для \\ оптимізаці цитокіново реакці при розвитку кардіосклеротичного процесу. \\ КЛЮЧОВІ СЛОВА: гіпоксія, дифузний кардіосклероз, цитокіновий профіль, триметазидин.
}

Вступ. Наукові дослідження з виявлення причин і факторів ризику серцево патологі свідчать про відсутність позитивно динаміки в кра нах світу з середнім і низьким рівнем економічносоціального розвитку за показниками захворюваності та смертності від серцево-судинно патологі [1]. Відомо, що більшість серцевих захворювань пов'язані з фіброзом міокарда [2]. Кардіосклероз із розвитком серцево недостатності становить значний інтерес для науковців медично галузі [3, 4 , 5] з огляду на значний відсоток маніфестаці гіпоксичних, токсичних, ендокринно-обмінних, стресорних ушкоджень міокарда при клінічно вираженій серцевій недостатності. Терміном «кардіосклероз» (синонім - «міокардіосклероз») називають розростання сполучно тканини в серцевому м'язі, зазвичай на місці загиблих м'язових волокон. Морфологічно розрізняють осередковий і дифузний кардіосклероз, за етіологією - постінфарктний, міокардитичний, кардіосклероз внаслідок кардіоміопатій і замісний кардіосклероз (фіброз міокарда) у результаті міокардіодистрофі різного генезу, в тому числі внаслідок гіпоксі міокарда при атеросклерозі вінцевих артерій серця (так званий атеросклеротичний кардіосклероз) і його поєднання з гіпертонічною хворобою (ангіогенний кардіосклероз). У зарубіжній літературі відповідні зміни у міокарді прийнято називати «diffuse myocardial fibrosis» або «fibrosis of myocardium» [3]. Залежно від етіологічного чинника, який викликав розростання сполучно тканини, існують певні особливості патогенезу [4], проте деякі клінічні дослідження довели [5], що у значно кількості пацієнтів у термінальній стаді серцево недостатності, незалежно від етіологі, виявлено накопичення антитіл до серцево тканини, що свідчить про гуморальну активацію і є показником прогресуючого перебігу захворювання.

Однією з провідних ланок розвитку кардіосклеротичного процесу $є$ зміни цитокіново регуляці. Цитокіни гуморальним шляхом контролюють і беруть участь у багатьох імунологічних та біохімічних процесах організму. Такі цитокіни, як інтерлейкіни, хемокіни, лімфокіни, монокіни, інтерферони є найважливішими чинниками регуляці захисних реакцій людини, у тому числі реакцій запалення та імунітету, і належать до числа біологічно активних молекул, які активно досліджують [5]. Запалення становить фундамент захисних реакцій та імунітету і є величезною медичною проблемою, тому $є$ наріжним каменем багатьох видів патологі (інфекці, пухлини, гепатит, туберкульоз, імунодефіцит, атеросклероз). Особливості запально реакці мають важливе значення і в досліджуваній патологі [6]. Дослідження J. Kuusisto et al. (2012 р.) доводять, що у розвитку серцево недостатності ключову роль відіграють фактори, що здатні ініціювати і підтримувати запалення на мінімальному рівні тривалий час, так зване «безмовне» або «Low-grade inflammation" [7].

Попередні дослідження доводять, що виражений вплив на перебіг кардіосклеротичного процесу мають індивідуальна реактивність та резистентність організму [8, 9]. Значний інтерес для науковців у даному контексті становить індивідуальна резистентність організму до гіпоксі, адже саме ішемічно-гіпоксичні впливи займають провідну ланку у патогенезі кардіосклерозу [6, 8-10].

3 огляду на вищенаведене доцільним $є$ дослідження вказаних ланок патогенезу кардіосклеротичного процесу залежно від стійкості організму до гіпоксі. Особливо актуальності набувають питання корекці даних порушень за допомогою різних патогенетичних впливів та, зокрема, засобів ендогенно кардіопротекці $[10,11]$ на різних етапах розвитку патологі. Нещодавніми дослідженнями було доведено, що цитокіни секретуються як імунокомпетентними клітинами, до яких можна віднести Т-лімфоцити, макрофаги і моноцити [12], так і неімунокомпетентними клітинами, зокрема кардіоміоцитами, ендотеліоцитами, фібробластами [13]. Цитокіни регулюють активацію, диферен- 
Оеляди літератури, ориаінальні дослідження, поеляд на проблему

ціювання, ріст, смерть і ефекторні функці різних типів клітин [12, 13], що робить х важливими факторами в патофізіологі кардіосклерозу і хронічно серцево недостатності $(\mathrm{XCH})$.

У наших попередніх роботах ми вже вивчали деякі особливості змін цитокінового профілю крові, а також особливості балансу про- та протизапальних цитокінів при експериментальному дифузному кардіосклерозі у щурів з різною стійкістю до гіпоксі [6], в той час як вплив ендогенно кардіопротекці на цитокіновий профіль крові при даній патологі залишається невивченим.

Мета дослідження. Вивчення особливостей змін цитокінового профілю крові при застосуванні триметазидину для корекці експериментального дифузного кардіосклерозу у щурів, залежно від $\mathrm{x}$ стійкості до гіпоксі .

Матеріал і методи дослідження. Експериментальне дослідження проведено на 96 статевозрілих білих нелінійних щурах-самцях масою 190-250 г, яких утримували на стандартному раціоні віварію. Тварин поділили на експериментальні групи, залежно від х стійкості до гіпобарично гіпоксі: низькостійкі (НГТ), середньостійкі (СГ) і високостійкі до гіпоксі тварини (ВГТ). Ця методика базується на визначенні часу виживання тварин у барокамері при розрідженні повітря до 30 мм рт. ст. (еквівалентно перебуванню на висоті 12000 метрів над рівнем моря). Експериментальне відтворення дифузного ішемічно-некротичного кардіосклерозу (ДІНКС) у тварин включало два етапи некротичного пошкодження кардіоміоцитів за катехоламіново-кальцієвим механізмом [9, 10]. Виведення тварин з експерименту здійснювали шляхом кровопускання під загальною анестезією за допомогою внутрішньоперитонеального введення тіопенталу натрію (50 мг/кг) [9].

Для ендогенно кардіопротекці при моделюванні ДІНКС вводили водну суспензію триметазидину в дозі 10 мг/кг внутрішньошлунково за допомогою зонда 1 раз на добу протягом усього періоду спостереження [11]. Цей препарат також вводили аналогічним способом тваринам контрольних груп з різною резистентністю до гіпоксі . Тварин поетапно виводили з експерименту через 7, 14 і 30 діб після моделювання ДІНКС, по 8 особин кожно групи. У сироватці крові визначали вміст ІЛ-1ß, IL-6, IL-10 [14]. Концентрацію цитокінів вивчали методом твердофазного імуноферментного аналізу з використанням наборів реагентів «ELISA Kit for Rat Uscn, Life Science Inc» відповідно до інструкцій фірми-виробника на аналізаторі STAT-FAX. Концентрацію цитокінів виражали у нг/л.

Усі експериментальні дослідження та евтаназію тварин проводили з дотриманням «Загальних етичних принципів експериментів на тваринах», ухвалених Першим національним конгресом 3 біоетики (Ки в, 2001), відповідно до Європейсько конвенці про захист хребетних тварин, що використовуються в дослідних та інших наукових цілях. Статистична обробка результатів виконана у відділі системних статистичних досліджень ДВНЗ «Тернопільський державний медичний університет імені І.Я. Горбачевського МОЗ Укра ни» в програмному пакеті Statsoft STATISTICA з використанням параметричних і непараметричних методів оцінки отриманих даних. Для всіх показників розраховували значення середнього арифметичного вибірки (M), похибку середнього (m). Достовірність різниці значень між незалежними кількісними величинами визначали при нормальному розподілі за критерієм Стьюдента, в інших випадках - за допомогою критерію Манна-У тні. Різницю між величинами вважали достовірною при величині $\mathrm{p}<0,05$.

Результати й обговорення. Експериментальне дослідження показало, що введення триметазидину тваринам контрольних груп з різною стійкістю до гіпоксі без моделювання патологі не вплинуло на концентрацію IЛ-1及, IL-6, IL-10. Однак виявлено зміни концентраці досліджуваних цитокінів у сироватці крові тварин, яким проводили метаболічну терапію триметазидином з першого дня моделювання ДІНКС.

На першому етапі спостереження, через 7 діб після моделювання ДІНКС та корекці триметазидином, вміст ІЛ- $1 \beta$ у сироватці крові тварин з низькою стійкістю до гіпоксі достовірно зростав на $47,9 \%(p<0,01)$, порівняно 3 показником контрольно групи НГТ (рис. 1). До наступного етапу спостереження - 14 діб ДІНКС, цей показник дещо знизився, але був вищим, ніж у контрольній групі НГ на 25,2\% (p<0,01). На етапі 30 днів моделювання ДІНКС на тлі триметазидину показник достовірно не відрізнявся від групи контролю.

У щурів із середньою стійкістю до гіпоксі зміни вмісту ІЛ-1 в сироватці крові були менш інтенсивними. Через 7 діб після моделювання ДІНКС показник був вище рівня контрольно групи СГТ на $33,2 \%$ ( $<<0,01)$. На наступних етапах спостереження показник знижувався, але залишався на 20,2\% вищим $(p<0,05)$, ніж у контрольній групі СТ через 14 діб ДКС, а через 30 діб - на 16,5 \% (p<0,05) .

Високостійкі до гіпоксі тварини на моделювання ДІНКС на тлі триметазидину зреагували менш інтенсивними змінами вмісту ІЛ- $1 \beta$ в сироватці крові. Через 7 діб після моделювання ДІНКС $x$ показник був на $23,9 \%(p<0,05)$ вищим, ніж у контрольній групі ВГ, а через 14 і 30 діб ДІНКС на тлі триметазидину показник достовірно не відрізнявся від групи контролю.

Концентрація ІЛ-6 у сироватці крові тварин за даних умов зазнавала менших змін, проте х аналіз не менш цікавий, з огляду на те, що цей цитокін 
має одночасно про- і протизапальний ефект [15]. Також доведена його роль в ініціаці проліферативних процесів у міокарді.

На першому етапі спостереження цей показник у НГТ був максимально підвищеним і відрізнявся від контрольно групи тварин з низькою стійкістю до гіпоксі на 41,8 \% (p<0,01) (рис. 2), через 14 діб ДІНКС на тлі триметазидину досліджуваний показник відрізнявся від контрольно групи тварин на 20,9\% (p<0,05), а через 30 діб ДІНКС на тлі триметазидину показник достовірно не відрізнявся від групи контролю.

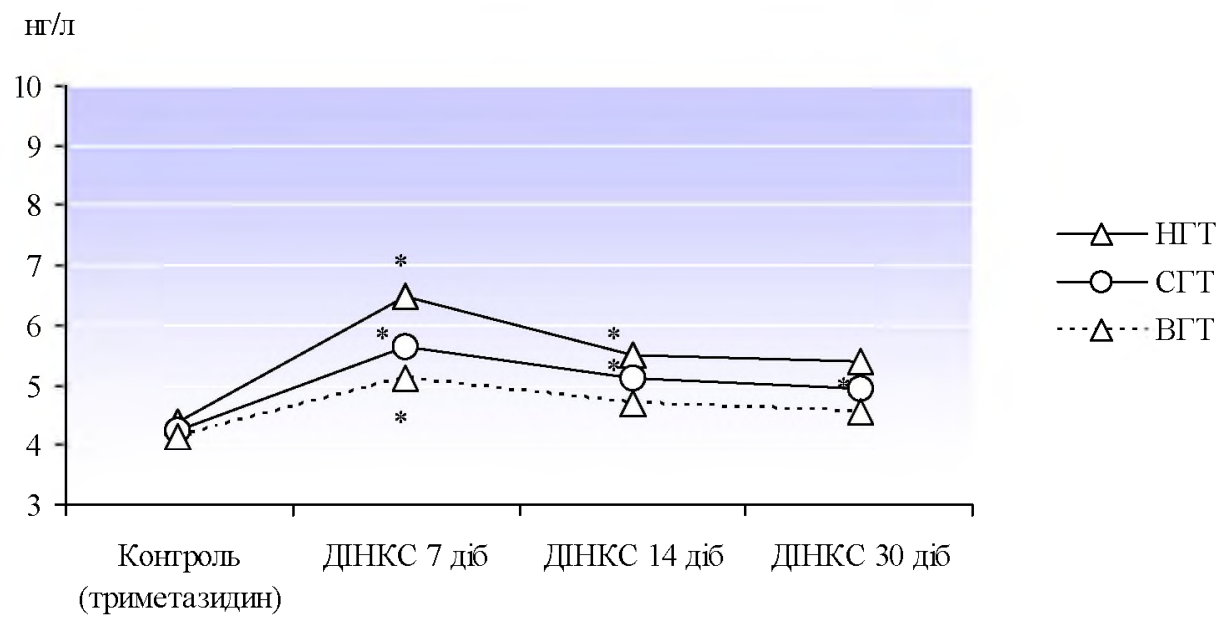

Рис. 1. Динаміка концентраці ІЛ- 1ß, нг/л, в сироватці крові щурів з різною стійкістю до гіпоксі при розвитку ДІНКС на тлі ранньо корекці триметазидином. (Примітка. * - p<0,05 - достовірність відмінностей порівняно з контрольною групою тварин з такою ж стійкістю до гіпоксі).

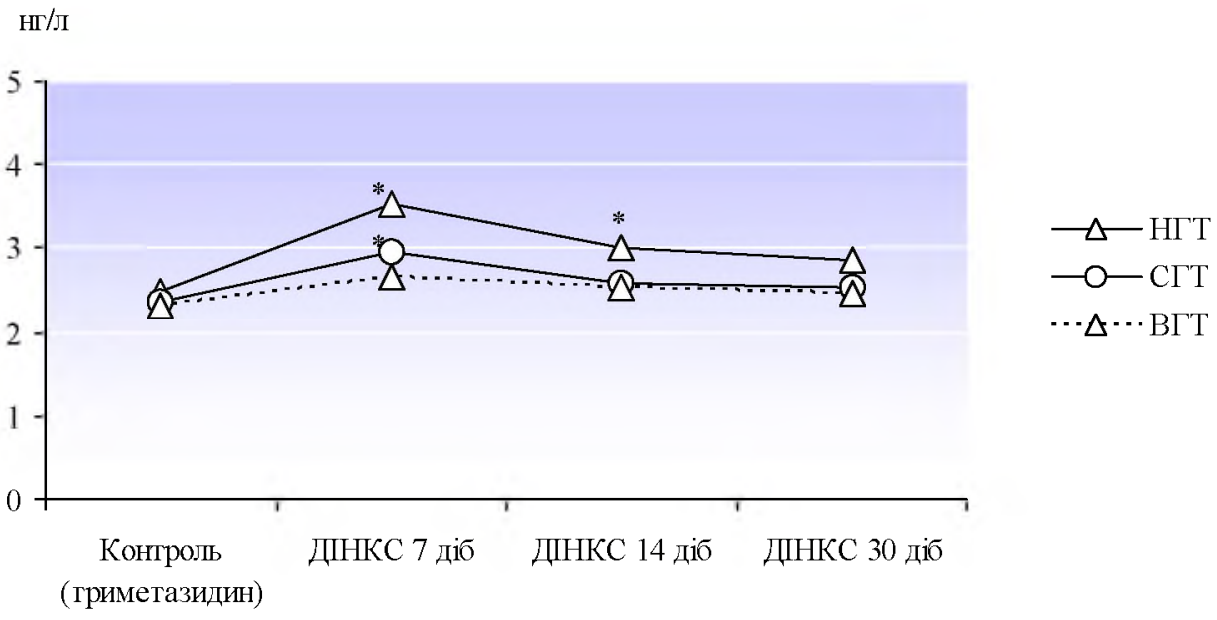

Рис. 2. Динаміка концентраці ІЛ-6, нг/л, в сироватці крові щурів з різною стійкістю до гіпоксі при розвитку ДІНКС на тлі ранньо корекці триметазидином. (Примітка. * - p<0,05 - достовірність відмінностей порівняно з контрольною групою тварин з такою ж стійкістю до гіпоксі ).

Концентрація ІЛ-6 у сироватці крові тварин з середньою стійкістю до гіпоксі була більшою, ніжу контрольній групі СГТ, на 25,0\% $(p<0,05)$ через 7 діб після моделювання ДІНКС та корекці триметазидином. На подальших етапах досліджуваний показник не відрізнявся від групи контролю СГТ.

У високостійких до гіпоксі тварин моделювання ДІНКС не супроводжувалося достовірними змінами концентраці ІЛ-6 у сироватці крові на усіх етапах розвитку патологі при ранній корекці триметазидином.

Характеризуючи зміни рівня протизапального цитокіну ІЛ-10 слід зазначити, що через 7 діб ДІНКС на тлі триметазидину концентрація ІЛ-10 в сиро- ватці крові групи НГТ достовірно зменшилась на $25,9 \%(p<0,001)$, порівняно з показником контрольно групи НГТ (рис. 3). До етапів спостереження 14 і 30 діб ДІНКС цей показник почав відновлюватися, але був нижчим, ніжу контрольній групі НГТ, відповідно на 18,6 \% (p<0,01) і 17,1\% $(p<0,05)$.

Реакція тварин з середньою і високою стійкістю до гіпоксі характеризується підвищенням продукці цитокіну протизапально ланки у відповідь на дану експериментальну модель на тлі триметазидину. Через 7 діб після моделювання ДІНКС у СП показник збільшився на 93,8 \% $(p<0,01)$ вище рівня контрольно групи. На наступних етапах 
нг/Л

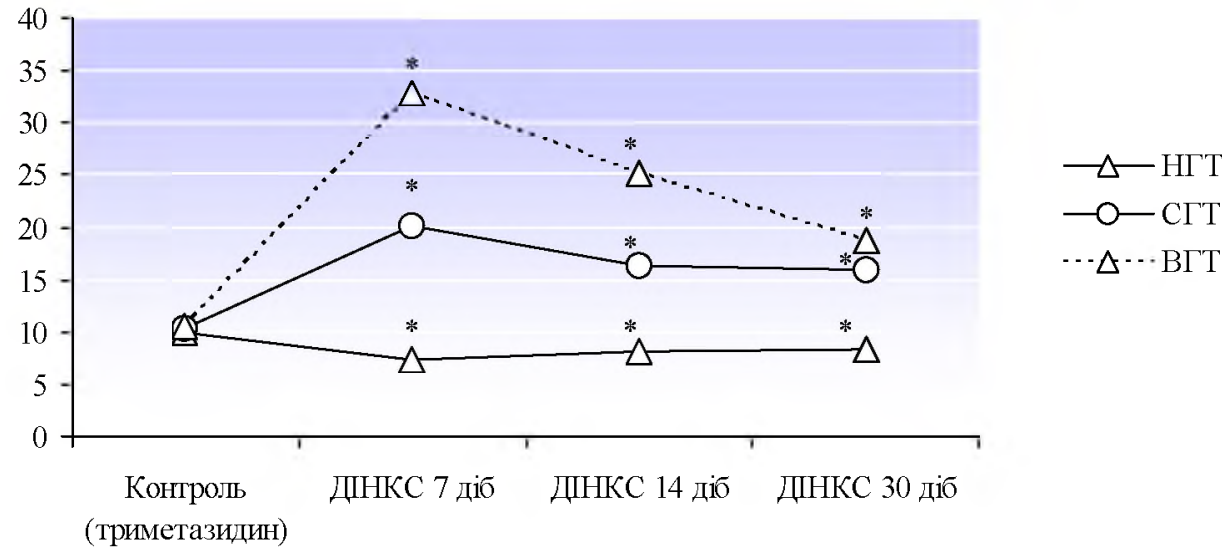

Рис. 3. Динаміка концентраці ІЛ- 10, нг/л, в сироватці крові щурів з різною стійкістю до гіпоксі при розвитку ДІНКС на тлі ранньо корекці триметазидином. (Примітка. * - p<0,05 - достовірність відмінностей порівняно з контрольною групою тварин з такою ж стійкістю до гіпоксі ).

спостереження показник утримувався на рівні, більшому, ніж у контрольній групі СГТ: на 56,7 \% ( $<<0,001)$ через 14 діб ДІНКС і на 53,4\% $(p<0,05)$ через 30 діб патологі на тлі триметазидину.

У ВГТ на етапі спостереження 7 діб ДІНКС на тлі триметазидину концентрація ІЛ-10 в сироватці крові була більшою в 3,1 раза $(p<0,001)$, через 14 діб - у 2,4 раза $(p<0,001)$, через 30 діб цей показник перевищував рівень групи контрольних тварин на 1,8 \% ( $p<0,001)$.

Отримані результати вказують на те, що триметазидин не пригнічує продукцію прозапальних і не викликає експресію протизапальних цитокінів, а, значить, не має протизапального ефекту, але, покращуючи метаболізм клітин тканини міокарда при пошкодженні $[9,11,16]$, сприяє послабленню прозапально та посиленню протизапально цитокіново реакці серця, що сповільнює розвиток сполучно тканини.

Відомо, що триметазидин селективно інгібує 3-кетоацил КоА-тіолазу - ключовий фермент вокиснення вільних жирних кислот, і підвищує активність піруватдегідрогенази - ферменту, що бере участь в окисненні глюкози [17]. У результаті відбувається метаболічне перемикання - зниження використання ліпідних субстратів для вироблення АТФ і збільшення споживання глюкози [18, 19]. Це сприяє зменшенню активності ПОЛ, що гальмує реалізацію так звано «ліпідно тріади», пошкодження біомембран, що підтверджується нашими дослідженнями з використанням триметазидину для корекці кардіосклерозу у щурів з різною стійкістю до гіпоксі [9]. Триметазидин має непрямий механізм антиоксидантно ді. Він є результатом зниження активаці тих клітин, які беруть участь в утворенні вільних радикалів: найчастіше це макрофаги, нейтрофільні гранулоцити, а також ендотеліоцити і клітини, що піддавалися впливу ішемі та репер- фузі. У цьому криється ще один дуже важливий механізм ді метаболічно терапі триметазидину, який можна розглядати як попереджувальний [9, 17]. Це дозволяє зменшити прояви феномена постстресорно ригідності міокарда, підвищити резистентність серця до гіпоксі . Ці ж клітини є головними продуцентами цитокінів при розвитку патологі міокарда, тому при зниженні триметазидином x активаці спостерігається оптимізація цитокіново реакці , а саме: зменшення продукці прозапальних цитокінів та збільшення продукці протизапальних цитокінів.

При аналізі реакці цитокінів на катехоламіново-кальцієве пошкодження і розвиток ДІНКС у щурів на тлі триметазидину, залежно від $x$ вроджено стійкості до гіпоксі, виявили, що найбільші відмінності були на першому етапі спостереження. Через 7 днів після моделювання ДІНКС у щурів з низькою стійкістю до гіпоксі концентрація ІЛ-1 $\beta$ в сироватці крові була більшою, ніж у СГ, на 14,5\% ( $p<0,05)$, а ІЛ-6 - на 19,7\% (p<0,05). Концентрація протизапального цитокіну ІЛ-10 на даному етапі у НГ була меншою у 2,7 раза ( $<<0,001)$, ніж у СП. Спостереження на подальших етапах не виявило достовірних відмінностей між низькостійкими і середньостійкими до гіпоксі тваринами за показниками ІЛ-1 $\beta$ і ІЛ-6, лише концентрація ІЛ-10 була меншою у НГТ у 2,0 рази $(\mathrm{p}<0,001)$ через 14 діб і у $1,9$ раза ( $p<0,001)$ через 30 діб ДІНКС на тлі триметазидину. Досліджувані показники концентраці ІЛ-1 1 і ІЛ-6 у тварин з високою стійкістю до гіпоксі достовірно не відрізнялися від показників СГТ, а концентрація протизапального цитокіну ІЛ-10 була більшою у ВГТ в 1,6 раза $(p<0,001)$ через 7 діб ДІНКС, на 1,5\% (p<0,001) через 14 діб і на 1,2\% $(p<0,001)$ через 30 діб ДІНКС на тлі триметазидину.

Глибше розуміння ролі цитокінів у патогенезі ДІНКС залежно від резистентності організму до 
гіпоксі дають результати досліджень впливу модуляторів гіпоксія-індукованого фактора-1 (HIF-1) $[20,21]$. Це має важливе значення у виникненні патофізіологічних змін гомеостазу в умовах нестачі кисню, а також ішемі. Активність кардіосклеротичного процесу підтримується хронічною гіпоксією, яка реалізується через хронічну ішемію тканини міокарда.

Механізми зміни в клітинах при гіпоксі частково вже вивчені. При короткочасній гіпоксі реалізуються захисні механізми, що сприяють виживанню клітин. Критичну роль у формуванні адекватно відповіді організму на гіпоксію відіграє гіпоксіяіндукований фактор (HIF), насамперед його $1 \alpha$-ізоформа (HIF-1 $\alpha)$ [20].

В умовах хронічно гіпоксі зростання рівня HIF-1 $\alpha$ призводить до незворотного пошкодження структур міокарда та розвитку фіброзу. Основними точками впливу при цьому є: безпосередня регуляція фіброгенезу, контроль епітеально-мезангіально трансформаці, модуляція процесів запалення, контроль життєвого циклу клітин.

Нещодавніми дослідженнями на експериментальній моделі нирково ішемі-реперфузі підтверджено позитивний вплив триметазидину [22], який проявлявся збільшенням вмісту нітритів і нітратів, гемоксигенази-1, а також стабілізацією HIF-1 $1 \alpha$, що підтверджує наявність у цього препарату протиішемічного ефекту. Серед інших «точок прикладання" триметазидину вченими E. N. Dedkova, L. K. Seidlmayer (2013р.) отримано переконливі дані про відновлення окиснювально-відновного балансу і мітохондріального мембранного потенціалу при експериментальній серцевій недостатності [23]. Ці дослідження доводять, що різна динаміка про- та протизапальних цитокінів у ході експериментів на тваринах з різною стійкістю до гіпоксі при розвитку ДІНКС на тлі триметазидину в значній мірі залежить від генетично запрограмованих механізмів.

Висновки. 1. Моделювання кардіосклеротичного процесу при застосуванні триметазидину характеризується найбільш вираженими змінами концентраці про- та протизапальних цитокінів на етапі спостереження 7 діб дифузного ішемічнонекротичного кардіосклерозу.

2. На всіх етапах спостереження дифузного ішемічно-некротичного кардіосклерозу на тлі триметазидину концентрація протизапального цитокіну ІЛ-10 у тварин з високою стійкістю до гіпоксі була більшою, ніжу щурів із середньою та низькою стійкістю до гіпоксі , а показники ІЛ-1ß і ІЛ-6 достовірно не відрізнялися.

3. Застосування триметазидину для корекці дифузного ішемічно-некротичного кардіосклерозу сприяло оптимізаці цитокінових реакцій, а саме: зменшенню продукці прозапальних цитокінів та збільшенню продукці протизапальних цитокінів.

Перспективи подальших досліджень. Доцільним $є$ подальше вивчення особливостей патогенетичного впливу препаратів ендогенно кардіопротекці на розвиток ДІНКС залежно від резистентності тварин до гіпоксі .

\section{ЛITЕРАТУРА}

1. Cardiovascular Risk and Events in 17 Low-, Middle-, and High-Income Countries / S. Yusuf, S. Rangarajan, K. Teo [et al.] // N. Engl. J. Med. - 2014. - Vol. 371, № 1. - P. 818827.

2. Krenning $G$. The origin of fibroblasts and mechanism of cardiac fibrosis / G. Krenning, E. M. Zeisberg, R. Kalluri // J. Cell. Physiol. 2010. - Vol. 225, № 3. - P. 631-637.

3. Evaluation of diffuse myocardial fibrosis in heart failure with cardiac magnetic resonance contrast-enhanced T1 mapping / lles L., Pfluger H., Phrommintikul A. [et al.] // J. Am. Coll. Cardiol. - 2008. - Vol. 4, № 52 (19). - P. 15741580.

4. The influence of aetiology on inflammatory and neurohumoral activation in patients with severe heart failure: a prospective study comparing Chagas' heart disease and idiopathic dilated cardiomyopathy / A. O. Mocelin, V. S. Issa, F. Bacal [et al.] // Eur. J. Heart Fail. - 2005. - Vol. 7, № 1. P. 869-873.

5. High proportion of patients with end-stage heart failure regardless of aetiology demonstrates anti-cardiac antibody deposition in failing myocardium: humoral activation, a potential contributor of disease progression / K. A. Youker,

C. Assad-Kottner, A. M. Cordero-Reyes [et al.] // Eur. Heart J. - 2014. - Vol. 35, № 16. - P. 1061-1068.

6. Сатурская А. С. Изменения цитокинового профиля крови при экспериментальном диффузном кардиосклерозе у крыс с различной устойчивостью к гипоксии / А. С. Сатурская, Ю. И. Бондаренко, В. Е. Пелых // J. of Education, Health and Sport. - 2015. - T. 5, № 2. - C. 6678.

7. Low-grade inflammation and the phenotypic expression of myocardial fibrosis in hypertrophic cardiomyopathy / J. Kuusisto, V. Кдrjд, P. Sipola [et al.] // Heart. - 2012. Vol. 98, № 13. - P. 1007-1013.

8. Сатурська Г. С. Особливості метаболізму сполучно тканини при експериментальному дифузному ішемічно-некротичному кардіосклерозі у щурів із різною стійкістю до гіпоксі / Г. С. Сатурська, Ю.І.Бондаренко // Вісник ВНМУ, - 2014. - Т. 18, № 2. - С. 425-429.

9. Сатурская А. С. Особенности кардиопротекторного эффекта триметазидина при экспериментальном кардиосклерозе у крыс с различной степенью чувствительности к гипоксии / А. С. Сатурская // Вестник Витебского ГМУ. - 2015. - Т. 14, № 1. - С. 28-34. 
Оеляди літератури, ориаінальні дослідження, поеляд на проблему

10. Пат. 66297 Укра на, МПК G 09 В 23/28. Спосіб моделювання дифузного кардіосклерозу / Хара М. Р., Боднар Я. Я., Сатурська Г. С., Пелих В. Є.; заявник і патентовласник Терн. держ. мед. ун-т ім. І. Я. Горбачевського. - № u 201108088 ; заявл. 29.06.11 ; опубл. 26.12.11, Бюл. № 24.

11. Данченко А. П. Влияние триметазидина, тиотриазолина, таурина и убихинона на гипохолестеринемическое действие симвастатина у крыс с экспериментальной гиперхолестеринемией / А. П. Данченко, О. О. Пентюк // Фармакология та врачебная токсикология. 2008. - № 5/6. - С. 63-68.

12. Симбирцев А. С. Цитокины в патогенезе инфекционных и неинфекционных заболеваний человека / А. С. Симбирцев // Медицинский академический журнал. - 2013. - № 3. - С. 18-41.

13. Dostal D. Cardiac fibroblast physiology and pathology / D. Dostal, S. Glaser, T. A. Baudino // Compr Physiol. - 2015. Vol. 1, № 5(2). - P. 887-909.

14. Сенников С. В. Методы определения цитокинов / С. В. Сенников, А. Н. Силков // Цитокины и воспаление. 2005. - T. 4, № 1. - C. 22-27.

15. Inflammatory and anti-inflammatory cytokines in chronic heart failure: potential therapeutic implications / P. Aukrust, L. Gullestad, T. Ueland [et al.] // Ann. Med. 2005. - Vol. 37, № 1. - P. 74-85.

16. Effects of trimetazidine on the Akt/eNOS signaling pathway and oxidative stress in an in vivo rat model of renal ischemia-reperfusion / A. Mahfoudh-Boussaid, K. Hadj Ayed Tka, M. A. Zaouali [et al.] // Ren Fail. - 2014. - Vol. 36, № 9. - P. 1436-1442.
17. Мойбенко А. А. Эндогенные механизмы кардиопротекции как основа патогенетической терапии заболеваний сердца / А. А. Мойбенко, В. Е. Досенко, А. Н. Пархоменко. - К. : Наукова думка, 2008. - 520 с.

18. Gupta R. Treatment of stable angina pectoris with trimetazidine modified release in Indian primary-care practice / R. Gupta, J. P. Sawhney, V. S. Narain // Am. J. Cardiovasc. Drugs. - 2005. - Vol. 5, № 5. - P. 325-329.

19. Marzilli M. Efficacy and tolerability of trimetazidine in stable angina: a meta-analysis of randomized, double-blind, controlled trials / M. Marzilli, W. W. Klein //Coron. Artery Dis. 2003. - Vol. 14, № 2. - P. 171-179.

20. Gao W. Femoral Artery Occlusion Increases Muscle Pressor Reflex and Expression of Hypoxia-Inducible Factor16 in Sensory Neurons / W. Gao, J. Li // J. Cardiovasc. Dis. 2013. - Vol. 1, № 2. - P. 34-40.

21. HIF- 16 and HIF- 26 induce angiogenesis and improve muscle energy recovery / $\mathrm{H}$. Niemi, K. Honkonen, P. Korpisalo [et al.] // Eur. J. Clin. Invest. - 2014. - Vol. 44, № 10. P. 989-999.

22. Effects of trimetazidine on the Akt/eNOS signaling pathway and oxidative stress in an in vivo rat model of renal ischemia-reperfusion / A. Mahfoudh-Boussaid, K. Hadj Ayed Tka, M. A. Zaouali [et al.] // Ren Fail. - 2014. - Vol. 36, № 9. - P. 1436-1442.

23. Mitochondria-mediated cardioprotection by trimetazidine in rabbit heart failure / E. N. Dedkova, L. K. Seidlmayer, L. A. Blatter // J. Mol. Cell. Cardiol. - 2013. - Vol. 59, № 1. P. 41-54.

\title{
PECULIARITIES OF CYTOKINE PROFILE CHANGES IN TRIMETAZIDINE CORRECTION OF EXPERIMENTAL DIFFUSE ISCHEMIC NECROTIC CARDIOSCLEROSIS IN RATS WITH DIFFERENT RESISTANCE TO HYPOXIA
}

\author{
SHEI «Ternopil State Medical University by I. Ya. Horbachevsky of MPH of Ukraine»
}

SUMMARY. Using endogenous metabolic therapy to correct the diffuse ischemic necrotic cardiosclerosis, the peculiarities of cytokine profile were studied in different periods of observation at animals with different resistance to hypoxia. The experiment confirmed the effectiveness of early use of trimetazidine to optimize cytokine response during the development of cardiosclerotic process.

KEYWORDS: hypoxia, diffuse cardiosclerosis, cytokines profiles, trimetazidine. 